\title{
Does International Criminal Court have Jurisdiction over the Destruction of Cultural Property by the Islamic State of Irac and Syria?
}

\author{
Bayu Sujadmiko, Desia Rakhma Banjarani ${ }^{2}$, Rudi Natamiharja ${ }^{3}$, \\ Desy Churul Aini ${ }^{4}$ \\ 1Faculty of Law, Universitas Lampung, Email: bayu.sujadmiko@fh.unila.ac.id \\ 2Faculty of Law, Universitas Lampung, Email: desiarahma7@gmail.com \\ ${ }^{3}$ Faculty of Law, Universitas Lampung,Email: rudi.natamiharja@fh.unila.ac.id \\ ${ }^{4}$ Faculty of Law, Universitas Lampung, Email: desy.churulaini@fh.unila.ac.id
}

\begin{tabular}{l}
\hline Info Article \\
\hline Received: $12^{\text {nd }}$ March 2021 \\
Accepted: $21^{\text {st } J u l y ~} 2021$ \\
Published: $31^{\text {st }}$ July 2021 \\
Keywords: \\
Cultural Property; Armed Conflict; \\
ICC; ISIS \\
Corresponding Author: \\
Bayu Sujadmiko,Email: \\
bayu.sujadmiko@fh.unila.ac.id \\
DOI: \\
10.24843/JMHU.2021.v10.i02.p01
\end{tabular}

\begin{abstract}
The cultural property becomes objects of destruction in armed conflicts, such as Syria and Iraq, which were carried out by ISIS squads (Islamic State of Iraq and Syria). For ISIS's actions, the ICC should judge ISIS. However, new problems will arise regarding the jurisdiction of the ICC to judge ISIS. Based on the explanation of this background, the question will arise: How are humanitarian law regulations related to protecting cultural property during armed conflict? And what is the regulation of the ICC's jurisdiction over the protection of cultural property in armed conflict by ISIS? The research in this article is normative legal research with the statue approach. According to humanitarian law, the research results show that the regulations relating to the protection of cultural property during armed conflict are contained in the 1954 Hague Convention, Additional Protocol I and Additional Protocol II of the Geneva Conventions of 1977. The destruction of cultural property carried out by ISIS is included in war crimes, one of the Rome Statute material jurisdictions. In this case, the Rome Statute applied by the ICC has juridical power to uphold justice and punish, including war crimes committed by ISIS. For the destruction of various cultural property in Iraq and Syria, ISIS can be judge by the ICC through a referral by the UN Security Council based on the provisions stipulated in the 1998 Rome Statute.
\end{abstract}

\section{Introduction}

Cultural property is important objects that must be protected because they hold a variety of stories in the past and can never be obtained in the present. ${ }^{1}$ The international community has long realized this important aspect of cultural property by establishing the United Nations Educational Scientific and Cultural Organization

\footnotetext{
1 Karen Angela Batara Tuppang, "Perlindungan Hukum Terhadap Hak Cipta Benda-Benda Bersejarah Menurut Undang-Undang Nomor 11 Tahun 2010 Tentang Cagar Budaya," Lex Et Societatis 7, no. 7 (2020), https://doi.org/https:/ /doi.org/10.35796/les.v7i7 26837.
} 
(UNESCO). ${ }^{2}$ Thus, it can be said that the international community has recognized the protection of cultural property for a long time. But lately, cultural property becomes a destruction object during a war or conflict area. ${ }^{3}$

Cultural property has serious vulnerabilities in the armed conflict in both international and non-international armed conflicts. ${ }^{4}$ One of the conflict areas that give destruction to the cultural property in Syria and Iraq, where one of the conflicts in Syria and Iraq, was led by ISIS squads (Islamic State of Iraq and Syria). ${ }^{5}$ Data collected by Syrian archeological protection organizations shows that over the past four years more than 900 historic archaeological sites and monuments have been looted, damaged or destroyed. ' ISIS has repeatedly released videos containing the destruction of ancient artifacts, such as the destruction of the Baalshamin Temple, Dura-Europos in eastern Syria (Pompei in the desert) and the Palmyra site, in August 2015. In Iraq, several historical sites built since the Mesopotamian period have been to dust. One of them is the Nimrud site south of Mosul, the Hatra site built since Roman colonial times, north of Nineveh. Some ISIS members are said to have sold several cultural objects on the black market for personal gain. The ISIS revealed its purpose in destroying several important monuments is to erase the cultural history of the Middle East.7 In addition, ISIS also destroyed the Great Mosque of Al Nuri and its Al Hadb minaret, an icon of Mosul, Iraq, for almost 840 years. ${ }^{8}$

According to international law, when war or armed conflict happened, it is living things that get protection and the protection object's cultural property. Protection of cultural property during a war is regulated in humanitarian law ${ }^{9}$ namely in the 1954 Hague Convention ${ }^{10}$ concerning Protection of Cultural Property during Armed Conflict. ${ }^{11}$ Based on the law that protects cultural property, ISIS's actions that destroy and sell various cultural property are violated humanitarian law.

2 Josephine Caust and Marilena Vecco, "Is UNESCO World Heritage Recognition a Blessing or Burden? Evidence from Developing Asian Countries," Journal of Cultural Heritage 27 (2017): 19, https:/ / doi.org/https:/ / doi.org/10.1016/j.culher2017.02.004.

3 Eric J SCHNITZER, "Perfecting War: Searching for the Silver Bullet," The United States Air Force's Centerfor Strategy and Technology, Netted Bugs and Bombs: Implications For, 2010. 22.

4 Taufik Rachmat Nugraha SH, "Urgensi Perlindungan Benda Bersejarah Di Indonesia Berdasarkan Hukum Humaniter Internasional," Mimbar Hukum-Fakultas Hukum Universitas Gadjah Mada 31, no. 3 (n.d.): 384-401, https:// doi.org/https:// doi.org/10.22146/jmh.46446.

${ }^{5}$ A Herlambang, "Mengurai Benang Kusut Konflik Di Suriah," Jurnal Transborder 1, no. 2 (2018), https://doi.org/10.23969/transborders.v1i2.794.

6 "ISIS 'jarah Secara Besar-Besaran' Situs Kuno Di Suriah - BBC News Indonesia" (BCC News Indonesia, 2015), https://www.bbc.com/indonesia/majalah/2015/09/150916_majalah_isis_budaya.

7 Ardita Mustafa, "Situs Sejarah Dunia Yang Dilenyapkan Teroris" (CNN Indonesia, 2016), https:/ /www.cnnindonesia.com/gaya-hidup/20161130144714-269-176339/situs-sejarahdunia-yang-dilenyapkan-teroris.

8 "7 Situs Bersejarah Yang Dihancurkan ISIS - Kumparan.Com" (Kumparan News, 2017), https://kumparan.com/kumparannews/7-situs-bersejarah-yang-dihancurkan-isis.

9 Buyung Adnan, "Instrumen Internasional Pokok Hak Asasi Manusia," Jakarta: Yayasan Obor Indonesia, 2006.4.

10 Situni F A Whisnu, "Identifikasi Dan Reformulasi Sumber-Sumber Hukum Internasional," Penerbit CV Mandar Maju, Bandung,1989. 10.

${ }^{11}$ ICCROM (International Centre for the Study of the Preservation and Restoration of Cultural Property), Protecting Cultural Heritage in Times of Conflict: Contributions from the Participants of 
Violations in humanitarian law or referred to as war crimes are international crimes, which are the International Criminal Court's material jurisdiction or International Criminal Court (ICC).12 For ISIS's heinous actions against the destruction of cultural property that violates humanitarian law, it can be said that the ICC as a permanent court to punish ISIS. 13 But to punish ISIS for its actions that violate humanitarian law is not an easy matter.

This is related to the existence of jurisdiction, limiting the ICC's performance to sue ISIS, i.e. territorial jurisdiction. Based on the Articles 12 and 13 Rome Statute, ${ }^{14}$ the ICC can apply their jurisdiction over anyone (both citizens of the 1998 Rome Statute or noncitizens) as long as the crime is committed in the territory of the 1998 Rome Statute State Party and the ICC can also apply their authority against international crime in the territory of any country (both territory Parties to the Rome Statute of 1998 or not a state party) as long as the perpetrators are citizens of a State Party. In this case, the crimes committed by ISIS revolve around the regions of Iraq and Syria. The two countries have not yet ratified the Rome Statute so that the ICC does not have jurisdiction over the two countries. However, this does not mean that the ICC can't sue ISIS based on the Rome Statute.

Based on the explanation of this background, a question will be raised in the formulation of the problem, namely how humanitarian law regulations related to protecting cultural property during armed conflict? And what is the regulation of the ICC's jurisdiction over the protection of cultural property in armed conflict by ISIS?

\section{Research Methods}

The research in this article is normative legal research. Normative legal research is in the form of legal products influenced by pure legal doctrines, such as studying certain laws or regulations. ${ }^{15}$ This research's approach method is the normative juridical method, which focuses on applicable legal provisions research.16 This study uses secondary legal data, which is legislation relating to issues, namely The Hague Convention of 1954 for Protecting Cultural Property in Armed Conflict, Additional

the International Course on First Aid to Cultural Heritage in Times of Conflict (Rome, Italy: MiBAC, 2012).

${ }^{12}$ Sefriani Sefriani, “Yurisdiksi ICC Terhadap Negara Non Anggota Statuta Roma 1998," Jurnal Hukum IUS QUIA IUSTUM 14, no. 2 (2007), https://doi.org/https://doi.org/1020885/iustum.vol14.iss2.art5.

${ }^{13}$ Kartini Sekartadji, "Prospek Dan Tantangan International Criminal Court," Jurnal Hukum \& $\begin{array}{lllll}\text { Pembangunan 34, no. } 2017): & \text { 91-109, }\end{array}$ https://doi.org/http://dx.doi.org/10.21143/jhp.vol34.no2.1431.

14 M Iman Santoso, "ICC 1998 Dan Konvensi TOC 2000: Sekilas Perbedaan Dan Persamaan Keduanya," Al-Qisth Law Review 1, no. 1 (2018): 29, https://jumal.umj.ac.id/index.php/alqisth-old/article/view/3249.

${ }^{15}$ Depri Liber Sonata, "Metode Penelitian Hukum Normatif Dan Empiris: Karakteristik Khas Dari Metode Meneliti Hukum," Fiat Justisia Jurnal Ilmu Hukum 8, no. 1 (2014): 15-35.

${ }^{16}$ Miranda Risang Ayu, Rika Ratna Permata, and Laina Rafianti, "Sistem Perlindungan Sumber Daya Budaya Tak Benda Di Palembang, Sumatera Selatan, Indonesia," Mimbar HukumFakultas Hukum Universitas Gadjah Mada 29, no. 2 (2017): 205-20, https://doi.org/https://doi.org/1022146/jmh.16671. 
Protocol I and Additional Protocol II of the Geneva Conventions of 1977, Rome Statute 1998, and other relevant legal researchers' writing.

\section{Result and Discussion}

\section{a. Cultural Property}

Cultural property is a form of evidence, sources, and a reflection of the long history of the creation of humans that have been recorded until now, so it can be called a cultural property. ${ }^{17}$ According to Davidson, cultural property is interpreted as a form of value from the past, which is a central element in the identity of a group or nation'.18 Historical relics of cultural property are priceless assets, which really need to be cared for and utilized properly. ${ }^{19}$ The protected cultural property is not an area which is natural character but rather the result of human culture in the form of objects from the past. ${ }^{20}$ Cultural property is a material property in the form of cultural property objects, cultural property buildings, cultural property structures, cultural property sites and cultural property areas on land and/or in water whose existence needs to be preserved because it has important values for history, science, education, religion and /or culture through a process of determination. ${ }^{21}$

Cultural property objects are the noblest relics for the national property because they contain the meaning of the ancestral culture's values for memories of all time. The most important thing in the cultural property as a historical/archaeological property is an object which is inseparable from the environment of the people who respect these relics. ${ }^{22}$ Cultural property has two major focuses on the protection of movable and immovable cultural property at a time of armed conflict, the second and fourth on the protection of movable cultural property in peacetime, and the third on the peacetime protection of, primarily, elements of immovable cultural heritage. .23

17 Ibnu Sodiq, Ufi Saraswati, and Ardhi Prabowo, "Pengembangan Model Konservasi Kesejarahan Di Semarang Berbasis Teknologi Informasi," Indonesian Journal of Conservation 7, no. 2 (2019), https://doi.org/https://doi.org/10.15294/ijc.v7i2.19006.

18 G. dan C Mc Conville Davison, A Heritage Handbook (St. Leonard, NSW: Allen \& Unwin, 1991).

${ }^{19}$ D A Wibowo, K Dimyati, and N Surbakti, "Perlindungan Hukum Terhadap Benda Cagar Budaya Studi Kasus Di Pengadilan Negeri Surakarta," 2016, 98-107, https://doi.org/https://doi.org/1023917/jurisprudence.v4i2.4212.

${ }^{20}$ Francisca Romana Harjiyatni and Sunarya Raharja, "Perlindungan Hukum Benda Cagar Budaya Terhadap Ancaman Kerusakan Di Yogyakarta," Mimbar Hukum-Fakultas Hukum Universitas Gadjah Mada 24, no. 2 (2012): 345-56, https://doi.org/https://doi.org/1022146/jmh.16138.

${ }^{21}$ Tuppang, "Perlindungan Hukum Terhadap Hak Cipta Benda-Benda Bersejarah Menurut Undang-Undang Nomor 11 Tahun 2010 Tentang Cagar Budaya."

${ }^{22}$ Ida Bagus Nyoman Wartha, "Manfaat Penting Benda Cagar Budaya Sebagai Peninggalan Sejarah/Arkeologi Untuk Kepentingan Agama, Sosial Budaya, Sosial Ekonomi, Pendidikan Dan Ilmu Pengetahuan (Studi Kajian Budaya)," Jurnal Santiaji Pendidikan 6, no. 2 (2016): 18996, https://doi.org/https://doi.org/10.1017/S0165070X11300022.

${ }^{23}$ Athanasios Yupsanis, "Cultural Property Aspects in International Law: The Case of the (Still) Inadequate Safeguarding of Indigenous Peoples'(Tangible) Cultural Heritage," Netherlands International Law Review 58, no. 3 (2011): 335-61. 


\section{b. Cultural Property Based on International Law}

Based on the previous chapter's explanation, it can be seen that cultural objects have an important role even in the cultural, social, and economic aspects. So that in the international scope, cases of theft of cultural property and trafficking of cultural property, namely the smuggling of historical goods with the motive of illegal trade in either export or import activities, are very threatening crimes. As a response to cases of crimes against cultural property, The UNESCO, a United Nations special agency engaged in the fields of education, science and culture, ${ }^{24}$ has initiated various conventions and regulations that protect cultural objects. ${ }^{25}$

In the context of protecting cultural objects throughout the world, UNESCO has formed several conventions that the international community has agreed to as a form of protection of each nation's cultural property. The conventions such as Universal Copyright Convention 1952 revised in 1971 and Convention on The Protection of The Diversity of Cultural Expressions 2005.26 In peacetime, cultural property is protected by Convention concerning the Protection of the World Cultural and Natural Property 1972; Convention for Safeguarding of The Intangible Cultural Heritage 2003.27

In this case, cultural property has an important position in the eyes of the world that we must guard and protect both when peaceful and during the war. According to Kusumaatmadja, as quoted by Haryomataram, war is a condition that a country or more country is involved in an armed dispute, accompanied by a statement of one of the other parties' intention. When war or armed conflict, cultural property is protected based on international humanitarian law. ${ }^{28}$ The purpose of humanitarian law is to protect those who suffer or who become victims of war, both those who are real and active in disputes (combat), as well as those who do not participate in disputes (civilians). ${ }^{29}$

The laws of war are not intended to prohibit war or enact laws that define war, but for humanitarian reasons to reduce or limit individuals' suffering and limit areas in which

24 Sigit Dwi Laksana, “Integrasi Empat Pilar Pendidikan (UNESCO) Dan Tiga Pilar Pendidikan Islam," Al-Idarah: Jurnal Kependidikan Islam 6, no. 1 (2016), https://doi.org/https://doi.org/1024042/alidarah.v6i1.789.

${ }^{25}$ Liliantoro Diyah Larosasari and Shary Charlotte Henriette Pattipeilohy, "Kebijakan Luar Negeri Indonesia Menyangkut Ketidakikutsertaan Dalam Ratifikasi Konvensi UNESCO 1970 Untuk Memberantas Pencurian Dan Perdagangan Gelap Benda Cagar Budaya," Journal of International Relations 5, no. 4 (2019): 678-85, https:// ejournal3.undip.ac.id/index.php/jihi/article/view/25035.

26 Dyah Permata Budi Asri, "Perlindungan Hukum Terhadap Kebudayaan Melalui World Heritage Centre UNESCO," Jurnal Hukum Ius Quia Iustum 25, no. 2 (2018): 256-76, https://doi.org/https://doi.org/10.20885/iustum.vol25.iss2.art3.

27 Erika J Techera, "Protection of Cultural Heritage Times of Armed Conflict: The International Legal Framework Revisited," Macquarie J. Int'l \& Comp. Envtl. L. 4 (2007): 1, researchonline.mq.edu.au.

28 Dyan Sitanggang, "Pengrusakan Tempat Bersejarah Dalam Perang Antarnegara Sebagai Pelanggaran Hukum Humaniter Internasional," Lex et Societatis 1, no. 2 (2013), https://doi.org/https://doi.org/10.35796/les.v1i2.1745.

${ }^{29}$ Haryomataram, Pengantar Hukum Humaniter (Jakarta: Raja Grafindo, 2005). 3. 
armed conflict is permitted. ${ }^{30}$ Humanitarian law only applies when an armed conflict ${ }^{31}$, but humanitarian law does not only regulate the procedures for war contained in Den Haag Law,32 but international humanitarian law also protects victims of the war contained in the Geneva law. ${ }^{33}$

\section{c. Protection of Cultural Property During Armed Conflict Based on Intemational Humanitarian Law}

International law does not offer a uniform, formal definition of safe havens for the endangered cultural property. ${ }^{34}$ Legal protection of cultural property during armed conflict is regulated in The Hague Convention of 1954 for Protecting Cultural Property in Armed Conflict. 35 This convention is considered the first agreement that included a general and detailed statement. ${ }^{36}$

Definitions of historical objects or historical relics or cultural objects as stipulated in Article 1 of the Hague Convention 1054 on the Protection of Cultural Property is detailed in three groups, namely: ${ }^{37}$

1) Movable or immovable objects which are very important for the culture of every country, such as architectural monuments, places of historical property, etc.;

2) Buildings whose main purpose is to preserve or exhibit invaluable cultural goods such as museums, libraries, archives, etc.;

3) Every center in a large number of cultural items.

According to Article 3, protection of cultural objects can take some actions, including: 38

${ }^{30}$ Muhammad Iqbal Asnawi, “Konsistensi Penegakan Hukum Humaniter Internasional Dalam Hubungan Antar Bangsa," Jurnal Hukum Samudra Keadilan 12, no. 1 (2017): 111-22, https:// jumalunsam.id/index.php/jhsk/article/view/95.

${ }^{31}$ Roberta Arnold and Noëlle N R Quénivet, International Humanitarian Law and Human Rights Law: Towards a New Merger in International Law (Brill, 2008). 357.

32 C. De Rover, To Serve and To Protect Acuan Universal Penegakan HAM (Jakarta: RajaGrafindo Persada, 2000). 100.

${ }_{33}$ Muhammad Rizal, “Eksistensi Prinsip-Prinsip Hukum Islam Terhadap Pengaturan Perang Dalam Hukum Humaniter Internasional" (Tadulako University, 2016), https://doi.org/https://doi.org/10.17304/ijil.vol16.2.748.

34 Andrzej Jakubowski, "International Protection of Cultural Heritage in Armed Conflict: Revisiting the Role of Safe Havens," Indonesian Journal of International Law 16, no. 2 (October 2019): 169-90, https://doi.org/10.17304/IJIL.VOL16.2.748.

35 Eka Martiana Wulansari, "Perlindungan Hukum Benda Budaya Dari Bahaya Konflik Bersenjata," Proceedings Universitas Pamulang 1, no. 1 (2016), http:// www.openjournal.unpam.ac.id/index.php/Proceedings/article/view/286.

${ }^{36}$ Sulaf Abdullah Hama Rashid, Bahaa Omer, and Khairy Ali, "Protection Of Cultural Property In The Light Of International Humanitarian Law," Journal of Critical Reviews 7, no. 6 (2020): 1021-28,https://doi.org/doi: 10.31838/jcr.07.06.176.

37 Sitanggang, "Pengrusakan Tempat Bersejarah Dalam Perang Antarnegara Sebagai Pelanggaran Hukum Humaniter Internasional."

38 Pramitha Astri Kurnia, Muchsin Idris, and Soekotjo Hardiwinoto, "Peranan United Nations Educational Scientific And Cultural Organization (Unesco) Dalam Perlindungan Benda-Benda Bersejarah Yang Hancur Akibat Konflik Bersenjata (Studi Kasus Perlindungan Benda-Benda 
1) Securing cultural objects. Every country hopes to secure their cultural property when the conflict starts or when in safe conditions by taking appropriate actions.

2) Cultural respect. Respect for the cultural property can be done by mutual respect for cultural property belonging to other countries. Stopping anyone who wants to damage, steal, plunder, abuse, and other vandalism acts and prohibit acts of retaliation directed at cultural objects. This is an obligation of each party to this convention.

The 1954 Hague Convention was supplemented by 3 related instruments, consisting of two protocols, namely Protocol ${ }^{39}$ concerning protection of cultural property in situations of armed conflict in 1954 and Protocol II concerning protection of cultural property in situations of armed conflict in 1999 and Protocol III concerning regulations for the implementation of the 1954 Den Haag conventions. The protocol that accompanies the 1954 Hague Convention can be an additional protocol, to provide an additional rights and responsible beside those regulated in the Hague Convention. The protocol has a special character and requires a separate ratification process from the Den Haag convention 1954.40

The relation to making criminal sanctions, each country must attach five serious violations to the codification of its national law in accordance with Article 15 of the Second Protocol, i.e.:41

1) Provide special protection to cultural property in the event of an attack.

2) Provide special protection to cultural property or the surrounding environment as support of military activities.

3) Widespread and evenly damaged cultural property under the special protection of the 1954 Hague Convention and the Second Protocol.

4) Making cultural property under the protection of the 1954 Hague Convention and the Second Protocol as objects of attack.

5) Theft, looting, abuse, or acts of vandalism directed at cultural property protected under the 1954 Hague Convention.

6) All types of the cultural property utilization that violated the 1954 Hague Convention and the Second Protocol.

7) All types of illegal excavations, illicit trade, transfer of ownership of cultural property which are prohibited in the 1954 Hague Convention and the Second Protocol.

Beside regulated in the Hague Law, protection of the cultural property is also regulated in Geneva Law, which is in Additional Protocol I and Additional Protocol II

Bersejarah Yang Hancur Akibat Konflik Bersenjata Di Suri," Diponegoro Law Journal 5, no. 4 (2017): 1-10, https:// ejournal3.undip.ac.id/index.php/dlr/article/view/15745.

${ }^{39}$ D P O' Connel, International Law for Students (Stevens and Sons, 1971). 214.

40 Hilda Hilda, "Kedudukan Dan Daya Mengikat Konvensi Denhaag 1954 Tentang Perlindungan Obyek Budaya Dalam Sengketa Bersenjata Terhadap Pihak-Pihak Yang Bersengketa (Amerika Serikat-Irak) Menurut Konvensi Wina 1969 Tentang Perjanjian Internasional," Jurnal Cita Hukum 1, no. 1 (2013), https:// doi.org/10.15408/jch.v1i1.2984.

${ }^{41}$ Kurnia, Idris, and Hardiwinoto, "Peranan United Nations Educational Scientific And Cultural Organization (UNESCO) Dalam Perlindungan Benda-Benda Bersejarah Yang Hancur Akibat Konflik Bersenjata (Studi Kasus Perlindungan Benda-Benda Bersejarah Yang Hancur Akibat Konflik Bersenjata DiSuri." 
of the Geneva Conventions of 1977. Article 53 Additional Protocol I outlines the prohibition on attacking and using historical value or culture value buildings to support military operations. Also determined in Point D of paragraphs 4 and 5 states that cultural property destruction is a grave offence and is a war crime. While in Protocol II, which contains regulations concerning the protection of victims of noninternational armed conflict, it also regulates the protection of cultural property and places of worship. Regulations on protecting cultural property are contained in article 16.42

Then, one of the criminal efforts in the act of destroying cultural property during a war can be seen in its implementation in the ad hoc court of the International Criminal Tribunal for the Former Yugoslavia (ICTY) which was formed to try the attack on the Old City of Dubrovnik. ICTY applies individual criminal responsibility to the perpetrators. ${ }^{43}$ Nowadays, the international community has a permanent court in the world that has jurisdiction to convict war criminals who violate humanitarian law is the International Criminal Court or ICC. ICC has a legal basis in trying international crimes which based on the Rome Statute.

The act of destroying cultural objects during the war in international and noninternational armed conflicts is a war crime as defined in Article 8 of the Rome Statute of the International Criminal Court (hereinafter referred to as the Rome Statute). It can also be identified as a crime against humanity under Article 7 paragraph (1) letter (h) of the Rome Statute. ${ }^{44}$ The cases of the destruction of cultural property that have been tried by the ICC, namely a mosque and a very historic Islamic cemetery in Timbuktu, a city in West Africa. The destruction occurred in June and July 2012 and was brought to the International Criminal Court (ICC) on August 22, 2016, with Ahmad Al Faki Al Mahdi.45

\section{3) ICC Jurisdiction Over the Protection of Cultural Property in Armed Conflict by ISIS}

Based on that explanation, it can be seen that cultural property in armed conflict is protected by humanitarian law. However, these regulations' existence does not rule out the possibility of destruction of cultural property when armed conflict occurs. It can be seen in the conflicts in Iraq and Syria by the Islamic State of Iraq and Syria or ISIS since occupying Mosul, Iraq, and a few central places in Syria. The ISIS group has damaged at least 23 tombs of Sufis and ancient mosques; 11 churches and monasteries; and 14 thousand-year-old ancient sites (including the ruins of Assyrian-era royal buildings).

\footnotetext{
42 Nuswantoro Dwiwamo Fadil Hidayat*, Joko Setiyono, “Aspek-Aspek Hukum Perlindungan Situs Budaya Dalam Perspektif Hukum Humaniter Internasional (Studi Kasus Perusakan Kota Kuno Palmyra Oleh Isis).," Diponegoro Law Review 6, no. 1 (2016): 1-12, http:/ /www.ejournals1.undip.ac.id/index.php/dlr/ ASPEK-ASPEK.

${ }^{43}$ Made Panji Wilimantara, I Made Pasek Diantha, and I Made Budi Arsika, "Penghancuran Benda Budaya (Iconoclast) Sebagai Kejahatan Terhadap Kemanusiaan," Kertha Negara : Journal Ilmu Hukum, 2016, Https://Ojs.Unud.Ac.Id/Index.Php/Kerthanegara/Article/View/21935.

${ }^{44}$ Ibid. 4.

45 Jufrian Murzal and Sophia Listriani, "Tanggung Jawab Peserta Tempur Dalam Melindungi Benda Cagar Budaya Dalam Suatu Konflik Bersenjata," Jurnal Ilmiah Mahasiswa Bidang Hukum $\begin{array}{lllll}\text { Kenegaraan no. } & 1,2017): & 2 & 12-21 \text {, }\end{array}$ https:/ / etd.unsyiah.ac.id/index.php?p=show_detail\&id=28248.
} 
That number does not include libraries and museums that store pre-Islamic artefacts and ancient literature. 46

As mentioned above, cultural property in armed conflict is protected by humanitarian law, but what happens to cultural property when armed conflict in Iraq and Syria by ISIS violates humanitarian law provisions. So that ISIS as the main suspect must be tried for war crimes he had been done. In other words, ISIS can be tried by the ICC for the crimes they have committed. However, to punish ISIS for their actions that violate humanitarian law is not an easy matter. It is related to ICC jurisdiction's existence that limits the ICC's performance to sue ISIS, namely territorial jurisdiction. It is based on the provisions contained in the Rome Statute. ${ }^{47}$ Based on the Rome Statute, the ICC can undertake their jurisdiction over anyone (whether a citizen of the Rome Statute 1998 or non-citizen) as long as the crime is occurring in the territory of the 1998 Rome Statute State Party and the ICC can also undertake their authority against international crime in the territory of any country (both territory Parties to the Rome Statute of 1998 or not a state party) as long as the perpetrators are citizens of a State Party Rome Statute 1998.

In this case, the crimes committed by ISIS revolve around the regions of Iraq and Syria. The two countries have not yet ratified the Rome Statute so that the ICC does not have jurisdiction over the two countries. In the absence of ICC jurisdiction in Iraq and Syria, ISIS cannot be reported to the ICC, and ICC cannot simply try ISIS without jurisdiction. Even so, that does not mean there is no way for the world to prosecute ISIS for all international crimes that they have already done. Because after all, the purpose of the establishment of the ICC was to improve distributive justice so that it would be unfair if ISIS could not be tried because the number of ISIS victims is not a bit. 48

Based on the provisions of the Rome Statute 1998, the ICC does not have jurisdiction for perpetrators of crimes who are not citizens of State Party of the Rome Statute, and crimes that have not been committed in a state party area. However, if international crimes are committed by non-citizens of the Rome Statute State Party, and the crimes that have not been committed in the state party area, the ICC can still prosecute those perpetrators based on the reference of the UN Security Council, as an institution that has a responsibility to maintain the peace and security on around the world. It is based on Article 13 Rome Statute. So that the ICC can try and punish ISIS but based on recommendations from the UN Security Council. However, until this time the Public Prosecutor of ICC has not yet investigated ISIS over the various crimes they have committed, so it can be said that the Security Council has not submitted a proposal to the ICC Public Prosecutor to investigate ISIS.

But that does not mean the Security Council is silent on crimes committed by ISIS, in this case, the Security Council has released several resolutions related to various crimes committed by ISIS, such as on December 16, 2015, the Security Council released a resolution S/PRST/2015/25 on investigations trafficking in persons, women and children carried out by ISIS. Then, on April 24, 2015, the Security Council released a

${ }^{46}$ Windu Jusuf, "Mengapa ISIS Keranjingan Menghancurkan Masjid? - Tirto.ID” (Tirto.id, 2017), https:/ / tirto.id/mengapa-isis-keranjingan-menghancurkan-masjid-crxL.

${ }^{47}$ Yulia Fitriliani, "Jurisdiksi Negara Dalam Kejahatan Terorisme," ADIL: Jurnal Hukum 4, no. 1 (2013): 207-24, https://doi.org/https:/ / doi.org/10.33476/ajl.v4i1.34.

48 Heni Siswanto, "Hukum Pidana Internasional Teori Dan Praktik," Bandar Lampung: Aura, 2016. 31 . 
resolution S/PRST/2015/10 on Syria's humanitarian crisis. Then in 2015, the Security Council released a resolution SC/12090 on suggestions for investigating illicit funds used by ISIS and investigations on ISIS members. The Security Council finally formed a resolution December 21, 2016, A/RES/71/248 to establish a fair and independent international mechanism to assist the investigation and prosecution of those responsible for the most serious crimes under international law committed in Syria since March 2011. The resolution was drafted by Liechtenstein and legitimated by 105 supporting states, 15 rejecting states and 52 states are abstaining. ${ }^{49}$ So far, it can be seen that the real efforts of the Security Council to prosecute ISIS have not produced any tangible results related to the punishment that ISIS deserves for any crime they have committed.

International law and humanitarian law strictly prohibit the destruction of cultural property in any part of the world. The Prison Law itself is the only appropriate form of punishment for war crimes; fines by themselves are not an appropriate punishment for war crimes. The punishment imposed must fulfil the crime factors is a violation, especially of the values protected by the international community. ${ }^{50}$

\section{Conclusion}

Protection of cultural property during armed conflict is regulated by the Hague humanitarian law and Geneva law. The Hague Law is regulated in the 1954 Hague Convention on the Protection of Cultural Property in Armed Conflict complemented by 3 related instruments and two protocols, namely Protocol I concerning the protection of cultural property in situations of armed disputes in 1954 and Protocol II concerning the protection of cultural objects in situations of armed conflict in 1999 and Protocol III concerning regulations for the implementation of the 1954 Hague Convention. In addition to being stipulated in the Hague Law, protection of cultural property also regulated in the Geneva Law, which is Additional Protocol I and Additional Protocol II of the Geneva Convention 1977.

The destruction of cultural property carried out by ISIS is included in the category of war crimes, one of the Rome Statute material jurisdictions. In this case, the Rome Statute applied by the ICC has juridical power to uphold justice and punish, including war crimes committed by ISIS. For the destruction of various cultural properties in Iraq and Syria, ISIS could be tried by the ICC through a referral by the UN Security Council based on the provisions stipulated in the Rome Statute 1998.

Based on the presentation of all papers, the author will suggest that it is necessary to take strict action to punish ISIS crimes to realise justice. As already stated, ISIS can be prosecuted by a referral mechanism through the UN Security Council. Thus the UN Security Council should immediately take action to sue ISIS so that the ICC can try it in accordance with applicable legal provisions.

49 UNSC, “UN Documents for Syria,” 2018, https://wwwsecuritycouncilreport.org/undocuments/syria/.

50 Wilimantara, Diantha, and Arsika, "Penghancuran Benda Budaya (Iconoclast) Sebagai Kejahatan Terhadap Kemanusiaan." 


\section{References}

Adnan, Buyung. "Instrumen Internasional Pokok Hak Asasi Manusia." Jakarta: Yayasan Obor Indonesia, 2006.

Arnold, Roberta, and Noëlle N R Quénivet. International Humanitarian Law and Human Rights Law: Towards a New Merger in International Law. Brill, 2008.

Asnawi, Muhammad Iqbal. "Konsistensi Penegakan Hukum Humaniter Internasional Dalam Hubungan Antar Bangsa." Jurnal Hukum Samudra Keadilan 12, no. 1 (2017): 111-22. https://ejurnalunsam.id/index.php/jhsk/article/view/95.

Asri, Dyah Permata Budi. "Perlindungan Hukum Terhadap Kebudayaan Melalui World Heritage Centre UNESCO." Jurnal Hukum Ius Quia Iustum 25, no. 2 (2018): 256-76. https://doi.org/https://doi.org/10.20885/iustum.vol25.iss2.art3.

Ayu, Miranda Risang, Rika Ratna Permata, and Laina Rafianti. "Sistem Perlindungan Sumber Daya Budaya Tak Benda Di Palembang, Sumatera Selatan, Indonesia." Mimbar Hukum-Fakultas Hukum Universitas Gadjah Mada 29, no. 2 (2017): 205-20. https://doi.org/https://doi.org/10.22146/jmh.16671.

Caust, Josephine, and Marilena Vecco. "Is UNESCO World Heritage Recognition a Blessing or Burden? Evidence from Developing Asian Countries." Journal of Cultural Heritage 27 (2017): https://doi.org/https://doi.org/10.1016/j.culher.2017.02.004.

Davison, G. dan C Mc Conville. A Heritage Handbook. St. Leonard, NSW: Allen \& Unwin, 1991.

Fadil Hidayat*, Joko Setiyono, Nuswantoro Dwiwarno. "Aspek-Aspek Hukum Perlindungan Situs Budaya Dalam Perspektif Hukum Humaniter Internasional (Studi Kasus Perusakan Kota Kuno Palmyra Oleh Isis)." Diponegoro Law Review 6, no. 1 (2016): 1-12 http://www.ejournal-s1.undip.ac.id/index.php/dlr/ ASPEKASPEK.

Fitriliani, Yulia. "Jurisdiksi Negara Dalam Kejahatan Terorisme." ADIL: Jurnal Hukum 4, no. 1 (2013): 207-24. https://doi.org/https://doi.org/10.33476/ajl.v4i1.34.

Harjiyatni, Francisca Romana, and Sunarya Raharja. "Perlindungan Hukum Benda Cagar Budaya Terhadap Ancaman Kerusakan Di Yogyakarta." Mimbar HukumFakultas Hukum Universitas Gadjah Mada 24, no. 2 (2012): 345-56. https://doi.org/https://doi.org/10.22146/jmh.16138.

Haryomataram. Pengantar Hukum Humaniter. Jakarta: Raja Grafindo, 2005.

Herlambang, A. "Mengurai Benang Kusut Konflik Di Suriah." Jurnal Transborder 1, no. 2 (2018). https://doi.org/10.23969/transborders.v1i2.794.

Hilda, Hilda. "Kedudukan Dan Daya Mengikat Konvensi Denhaag 1954 Tentang Perlindungan Obyek Budaya Dalam Sengketa Bersenjata Terhadap Pihak-Pihak Yang Bersengketa (Amerika Serikat-Irak) Menurut Konvensi Wina 1969 Tentang Perjanjian Internasional." Jurnal Cita Hukum 1, no. 1 (2013). https://doi.org/10.15408/jch.v1i1.2984.

ICCROM (International Centre for the Study of the Preservation and Restoration of Cultural Property). Protecting Cultural Heritage in Times of Conflict: Contributions from the Participants of the International Course on First Aid to Cultural Heritage in Times of Conflict. Rome, Italy: MiBAC, 2012

Jakubowski, Andrzej. "International Protection of Cultural Heritage in Armed Conflict: Revisiting the Role of Safe Havens." Indonesian Journal of International Law 16, no. 2 (October 2019): 169-90. https://doi.org/10.17304/IJIL.VOL16.2.748.

Kurnia, Pramitha Astri, Muchsin Idris, and Soekotjo Hardiwinoto. "Peranan United Nations Educational Scientific And Cultural Organization (Unesco) Dalam 
Perlindungan Benda-Benda Bersejarah Yang Hancur Akibat Konflik Bersenjata (Studi Kasus Perlindungan Benda-Benda Bersejarah Yang Hancur Akibat Konflik Bersenjata Di Suri." Diponegoro Law Journal 5, no. 4 (2017): 1-10. https://ejournal3.undip.ac.id/index.php/dlr/article/view/15745.

Laksana, Sigit Dwi. "Integrasi Empat Pilar Pendidikan (UNESCO) Dan Tiga Pilar Pendidikan Islam." Al-Idarah: Jurnal Kependidikan Islam 6, no. 1 (2016). https://doi.org/https://doi.org/10.24042/alidarah.v6i1.789.

Larosasari, Liliantoro Diyah, and Shary Charlotte Henriette Pattipeilohy. "Kebijakan Luar Negeri Indonesia Menyangkut Ketidakikutsertaan Dalam Ratifikasi Konvensi UNESCO 1970 Untuk Memberantas Pencurian Dan Perdagangan Gelap Benda Cagar Budaya." Journal of International Relations 5, no. 4 (2019): 67885. https://ejournal3.undip.ac.id/index.php/jihi/article/view/25035.

Murzal, Jufrian, and Sophia Listriani. "Tanggung Jawab Peserta Tempur Dalam Melindungi Benda Cagar Budaya Dalam Suatu Konflik Bersenjata." Jurnal Ilmiah Mahasiswa Bidang Hukum Kenegaraan 1, no. 2 (2017): 12-21. https: //etd.unsyiah.ac.id/index.php?p=show_detail\&id=28248.

O'Connel, D P. International Law for Students. Stevens and Sons, 1971.

Rashid, Sulaf Abdullah Hama, Bahaa Omer, and Khairy Ali. "Protection Of Cultural Property In The Light Of International Humanitarian Law." Journal of Critical Reviews 7, no. 6 (2020): 1021-28. https://doi.org/doi: 10.31838/jcr.07.06.176.

Rizal, Muhammad. "Eksistensi Prinsip-Prinsip Hukum Islam Terhadap Pengaturan Perang Dalam Hukum Humaniter Internasional." Tadulako University, 2016. https://doi.org/https://doi.org/10.17304/ijil.vol16.2748.

Rover, C. De. To Serve and To Protect Acuan Universal Penegakan HAM. Jakarta: RajaGrafindo Persada, 2000.

Santoso, M Iman. "ICC 1998 DAN Konvensi TOC 2000: Sekilas Perbedaan Dan Persamaan Keduanya." Al-Qisth Law Review 1, no. 1 (2018): 29. https://jurnal.umj.ac.id/index.php/al-qisth-old/article/view/3249.

SCHNITZER, Eric J. "Perfecting War: Searching for the Silver Bullet." The United States Air Force's Center for Strategy and Technology, Netted Bugs and Bombs: Implications For, 2010.

Sefriani, Sefriani. "Yurisdiksi ICC Terhadap Negara Non Anggota Statuta Roma 1998." Jurnal Hukum IUS QUIA IUSTUM 14, no. 2 (2007). https://doi.org/https://doi.org/10.20885/iustum.vol14.iss2.art5.

Sekartadji, Kartini. "Prospek Dan Tantangan International Criminal Court." Jurnal Hukum $\mathcal{E}$ Pembangunan 34, no. 2 (2017): 91-109. https://doi.org/http://dx.doi.org/10.21143/jhp.vol34.no21431.

$\mathrm{SH}$, Taufik Rachmat Nugraha. "Urgensi Perlindungan Benda Bersejarah Di Indonesia Berdasarkan Hukum Humaniter Internasional." Mimbar Hukum-Fakultas Hukum Universitas Gadjah Mada 31, no. 3 (n.d.): 384-401. https://doi.org/https://doi.org/10.22146/jmh.46446.

Siswanto, Heni. "Hukum Pidana Internasional Teori Dan Praktik." Bandar Lampung: Aura, 2016.

Sitanggang, Dyan. "Pengrusakan Tempat Bersejarah Dalam Perang Antarnegara Sebagai Pelanggaran Hukum Humaniter Internasional." Lex et Societatis 1, no. 2 (2013). https://doi.org/https://doi.org/10.35796/les.v1i2.1745.

Sodiq, Ibnu, Ufi Saraswati, and Ardhi Prabowo. "Pengembangan Model Konservasi Kesejarahan Di Semarang Berbasis Teknologi Informasi." Indonesian Journal of Conservation

no.

2

(2019). 
https://doi.org/https://doi.org/10.15294/ijc.v7i219006.

Sonata, Depri Liber. "Metode Penelitian Hukum Normatif Dan Empiris: Karakteristik Khas Dari Metode Meneliti Hukum." Fiat Justisia Jurnal Ilmu Hukum 8, no. 1 (2014): 15-35.

Techera, Erika J. "Protection of Cultural Heritage Times of Armed Conflict: The International Legal Framework Revisited." Macquarie J. Int'l E Comp. Envtl. L. 4 (2007): 1. researchonline.mq.edu.au.

Tuppang, Karen Angela Batara. "Perlindungan Hukum Terhadap Hak Cipta BendaBenda Bersejarah Menurut Undang-Undang Nomor 11 Tahun 2010 Tentang Cagar Budaya." Lex Et Societatis 7, no. 7 (2020). https://doi.org/https://doi.org/10.35796/les.v7i7.26837.

Wartha, Ida Bagus Nyoman. "Manfaat Penting Benda Cagar Budaya Sebagai Peninggalan Sejarah/Arkeologi Untuk Kepentingan Agama, Sosial Budaya, Sosial Ekonomi, Pendidikan Dan Ilmu Pengetahuan (Studi Kajian Budaya)." Jurnal Santiaji Pendidikan 6, no. 2 (2016): 189-96. https://doi.org/https://doi.org/10.1017/S0165070X11300022.

Whisnu, Situni F A. "Identifikasi Dan Reformulasi Sumber-Sumber Hukum Internasional." Penerbit CV Mandar Maju, Bandung, 1989.

Wibowo, D A, K Dimyati, and N Surbakti. "Perlindungan Hukum Terhadap Benda Cagar Budaya Studi Kasus Di Pengadilan Negeri Surakarta," 2016, 98-107. https://doi.org/https://doi.org/10.23917/jurisprudence.v4i2.4212.

Wilimantara, Made Panji, I Made Pasek Diantha, and I Made Budi Arsika. "Penghancuran Benda Budaya (Iconoclast) Sebagai Kejahatan Terhadap Kemanusiaan." Kertha Negara: Journal Ilmu Hukum, 2016. https://ojs.unud.ac.id/index.php/Kerthanegara/article/view/21935.

Wulansari, Eka Martiana. "Perlindungan Hukum Benda Budaya Dari Bahaya Konflik Bersenjata." PROCEEDINGS UNIVERSITAS PAMULANG 1, no. 1 (2016). http://www.openjournal.unpam.ac.id/index.php/Proceedings/article/view/28 6.

Yupsanis, Athanasios. "Cultural Property Aspects in International Law: The Case of the (Still) Inadequate Safeguarding of Indigenous Peoples'(Tangible) Cultural Heritage." Netherlands International Law Review 58, no. 3 (2011): 335-61.

\section{Website}

"7 Situs Bersejarah Yang Dihancurkan ISIS - Kumparan.Com." Kumparan News, 2017. https://kumparan.com/kumparannews/7-situs-bersejarah-yang-dihancurkanisis.

“ISIS 'jarah Secara Besar-Besaran' Situs Kuno Di Suriah - BBC News Indonesia." BCC News Indonesia, 2015. https://www.bbc.com/indonesia/majalah/2015/09/150916_majalah_isis_buda ya.

Jusuf, Windu. "Mengapa ISIS Keranjingan Menghancurkan Masjid? - Tirto.ID." Tirto.id, 2017. https://tirto.id/mengapa-isis-keranjingan-menghancurkanmasjid-crxL.

Mustafa, Ardita. "Situs Sejarah Dunia Yang Dilenyapkan Teroris." CNN Indonesia, $2016 . \quad$ https://www.cnnindonesia.com/gaya-hidup/20161130144714-269176339/situs-sejarah-dunia-yang-dilenyapkan-teroris.

UNSC. "UN Documents for Syria," 2018. https://www.securitycouncilreport.org/undocuments/syria/. 